\title{
NAVORSING OP DIE GEBIED VAN DIE
}

\section{SOSIALE WETENSKAPPE}

In Hollands is die woord scientia vertaal met wetenskap, wat sowel die natuur- as die geesteswetenskappe insluit, waardeur die woord sy oorspronklike betekenis behou. Die neiging bestaan om die Engels science met wetenskap in Afrikaans te vertaal, waarmee dan eintlik die natuurwetenskap bedoel word. Hierdeur word verwarring veroorsaak, omdat wetenskap die natuur- sowel as die sosiale of geesteswetenskappe insluit. Met Sosiale Wetenskappe word hier bedoel die hele veld van wetenskappe wat nie onder die natuurwetenskappe inbegrepe is nie. Sommige mag verkies om hierna te verwys as geesteswetenskappe.

Dit is nodig om helderheid oor die begrippe te hê as navorsing onder oënskou geneem word.

Beplanning is die sleutelwoord van ons 'yd. Meer as ooit word daar besef dat ontwikkeling en vooruitgang nie langer toevallig kan geskied nie. Beplanning is nodig om die lewenspeil van alle lede van die samelewing te verhoog. Deur wetenskaplike beplanning word moerasse deur lushowe, agterbuurtes, deur menswaardige buurtes, toestande van siekte, ondervoeding en gebrek deur toestande van gesondheid en oorvloed vervang. Maar alle beplanning berus op navorsing. So het navorsing die wagwoord geword.

Bedrae wat in bykans alle lande van die wêreld aan navorsing bestee word, is steeds besig om hoër en hoër te styg. Die oogmerk skyn te wees: leierskap deur navorsing.

In 'n klein pamfletjie, „You and Research", uitgegee deur die American Vocational Association (A.V.A.), word op egte reklame-wyse op die navorsingsbewustheid van die Amerikaners gewys:

„America is 'research-minded', whether the problem be designing shock absorbers for atomic submarines, improving pressure saucepans, finding cures for cancer, or developing seedless watermelons".

Raskin in The New Times Magazine laat hom as volg uit:

„The research tide is sweeping toward new high levels in every field from aircraft to soup".

In sy voorwoord tot die pamfletjie "You and Research" skryf die 
Voorsitter van die Komitee vir Navorsing en Publikasies van A.V.A.:

„More important to progress in vocational education than the establishment of specialized agencies of research - significant as they may be - is the development of a research attitude in every vocational educator, from the state director to the local co-ordinator and teacher".

Interessant is die uitlatings van enkele vooraanstaande Amerikaners oor navorsing in hul land:

1. George A. Fern, Director, Education Department, National Association of Manufacturers:

„The wonder of America is its unbelieveable industrial productivity its unparalleled technological advances, and its standard of living for all Americans unsurpassed on earth ..." en verder: „Industry relies upon and invests heavily in research".

2. Ezra Taft Benson, Secretary, United States Dept. of Agriculture: „Take away the results of the past 75 years of agricultural research and education in this country and you would reduce this nation to a fifth-rate nation".

3. Donald Greenway, Member of the National Council on Hotel and Restaurant Education:

„Research is the foundation of future steps in the development of any industry. Now more than ever before research is needed in the hotel and restaurant industry in order to prepare the industry for the future. Sound business judgment must be based on the facts: the future rests in better understanding of marketing, economics, personnel, finance, and profit making".

4. Lawrence A. Kimpton, Kanselier van die Universiteit van Chicago: „Central to research in the social sciences is the problem of education, and it is crucial to our national welfare. Justifiable confidence in the future of our democracy lies in universal education programs of a quality not achieved as yet in our most favored communities. I take it as axiomatic that such programs can be developed only through the highest quality of research in education and the immediate translation of such research into the schools by gifted and thoroughly trained teachers and administrators".

5. Arthur E. Traxler, van die Educational Records Bureau: „The development and extension among greater numbers of people of a research attitude - an attitude of search for truth - can 
be a powerful force making for stability and reason in a conflicting world".

6. Nelson N. Foote, Direkteur van die Family Study Centre, Universiteit van Chicago:

„As a nation Americans are becoming social-science-minded. They look to science to approve or repudiate their notions of which procedures are effective and which are ineffective for enlarging their understanding, so that family welfare can be forwarded matter-offactly and confidently. This means a demand for more experimental research than in the past, and for the lifting of its standards and relevance".

Te oordele aan hierdie uitlatings van vooraanstaande persone moet ons toegee dat die Amerikaners nie alleen "research-minded" is nie, maar ook wel ,social-science-minded".

Wat egter is die feite?

Volgens Good and Scates in hul Methods of Research het die uitgawe aan navorsing aan die natuur- en biologiese wetenskappe in die jare 1920-'30 meer as verdubbel. In die volgende 10 jaar, d.w.s. van 1930-'40, het dit weer verdubbel. Maar daarna versnel die pas sodat die 1940-uitgawes teen 1943 reeds verdubbel en in 1947 verdriedubbel het. Die nywerhede het in 1940 agt maal soveel aan navorsing spandeer as in 1920 en in 1947 was die uitgawe vyftien maal so groot as vir 1920, as atoomnavorsing nie ingesluit word nie.

Volgens die American Society of Mechanical Engineers het die getal ingenieurs en natuurwetenskaplikes wat met navorsing- of ontwikkelingsprojekte besig was gestyg van 20,000 in 1939 na plus minus 170,000 in 1957.

En nog is daar mense wat selfs in Amerika beweer dat die jeug in groter getalle in die ingenieurs- en wiskundige wetenskappe opgelei moet word, of hulle moet Russies leer.

Volgens die National Association of Manufacturers is daar in 1953 slegs $2 \frac{1}{2}$ biljoen dollar aan navorsing en ontwikkeling in die V.S.A. bestee, teenoor 4 biljoen dollar teenswoordig, teenoor 'n geraamde 10 biljoen dollar in 1973 .

Fondse vir navorsing word beskikbaar gestel deur die Federale Regering, staats- en plaaslike owerhede, "geleerde" verenigings, vrywillige organisasies en 'n groot aantal private ondernemings en indiwidue, maar veral ook deur die nywerhede. Miskien kan enkele voorbeelde ons ' $n$ begrip gee van die nywerhede se bydrae tot navorsing. In 1956 
het die General Motors Corporation 150,000,000 dollar beskikbaar gestel vir die oprigting en toerusting van 'n nuwe navorsingslaboratorium, die nuutste van 'n reeks nywerheidslaboratoria waarin sowat 1,000,000 natuurwetenskaplikes, ingenieurs en tegnici navorsing doen om beter dinge in die toekoms te skep.

Volgens Raskin in The New York Times Magazine bestee die nywerhede in die V.S.A. sowat 5,000,000,000 dollar jaarliks aan navorsing.

Uit hierdie massapogings van die V.S.A. blyk duidelik dat daar 'n element van vrees vir Rusland bestaan:

"The Soviet leaders have made it clear that they intend and expect to outstrip the U.S.A. in production of all the goods that make for human well-being". (Raskin).

Ons wil nie meer groot syfers aanhaal nie, maar slegs verwys daarna dat groot nywerhede soos General Electric, Bell Telephones, e.a. elk oor hul eie groot, goed toegeruste navorsingslaboratoria beskik.

Wanneer 'n mens tot 'n waardering probeer kom van die verhouding van die bedrae wat aan die natuur- en sosiale wetenskappe onderskeidelik bestee word, kom 'n mens voor sekere probleme te staan. Die omvang en betekenis van navorsing in die twee groot velde kan nie in terme van geld teen mekaar opgeweeg word nie. In die veld van die natuurwetenskappe is navorsing veel duurder, omdat veel meer geld in laboratoria en apparaat belê moet word.

Nietemin moet daar gewaak word dat navorsing op die gebied van die sosiale wetenskappe nie agterbly nie. Dit skyn of daar allerweë besef word dat so 'n toestand reeds aan die ontwikkel is. Die A.V.A. (bo aangehaal) meen „... the entire educational profession has lagged behind as the rest of America's enterprise turned to research to help solve their problems and build their future".

Daar is ook die geval van die nyweraar wat aan die Streeksuperintendent van Onderwys gesê het:

„Mister Superintendent, if we spent as little money on research in our organization as you do in your schools, we would be out of business tomorrow".

Ook in Suid-Afrika is die gedagte meermale uitgespreek dat daar in verhouding tot die natuurwetenskappe veels te min aan navorsingswerk op die gebied van die sosiale wetenskappe bestee word.

Die vraag ontstaan welke plek die universiteit as inrigting in die hele kader van navorsing inneem of behoort in te neem? 
Dit blyk dat te midde van die talle inrigtings wat in die V.S.A. nie alleen met die bevordering van navorsing besig is nie maar ook werklik navorsing onderneem, die universiteite steeds 'n belangrike plek inneem.

Verskeie inrigtings onder beheer van die Federale Regering soos die Departemente van Landbou, Handel, Verdediging, Arbeid, Federal Security Agency the Veteran's Administration, die Atomic Energy Commission, e.a. onderneem nie alleen navorsing op groot skaal nie, maar sluit met die universiteite ooreenkomste vir navorsing en vir die opleiding van wetenskaplikes van alle kategorieë. Gedurende 1949 het die Federale Regering $\mathbf{1 . 2}$ biljoen dollar aan navorsing bestee, waarvan 96 miljoen dollar aan die universiteite vir dié doel toegeken is.

Die houding van die Amerikaanse regering teenoor navorsing blyk uit die volgende aanhaling uit die begrotingsboodskap wat pres. Truman in 1952 aan die Kongres gestuur het:

„During the last decades we have seen how basic scientific research can alter the foundations of world power. We have seen that this research yields a stream of new knowledge which fortifies our economic welfare as well as our national strength. We have learned that a strong, steady, and wide ranging effort in science is as essential to our sustained national security as the production of weapons and the training of military personnel".

Van die groot sg. filantropiese organisasies soos die Ford Foundation, Rockefeller Foundation en die Carnegie-korporasie word skenkings aan universiteite en ander instansies gemaak waarby veral die onderwys, sosiale wetenskappe en gesondheid voordeel trek.

So het o.a. die Vrye Universiteit van Berlyn, vir die oprigting van geboue en die universiteite van Frankfurt en Chicago ruim skenkings van die Ford Foundation ontvang. Die Rockefeller Foundation is beter bekend vir sy werk op die gebied van gesondheid en medisyne.

'n Hele reeks universiteite, waaronder dié van California, Chicago, Columbia, Cornell, Michigan, Ibadan (Nigerië) e.a., het reeds ruim skenkings van die Carnegiekorporasie ontvang.

Die Amerikaanse universiteite het lankal tot die ontdekking gekom dat dit nie vir hul doserende personeel alleen moontlik is om in die groot behoefte van navorsing te voorsien nie, derhalwe was hul genoodsaak om inrigtings vir dié doel in die lewe te roep. In die 1950uitgawe van A Directory of Social Science Research Organisations in Universities and Colleges wat deur die Social Science Research Council uitgegee is, verskyn die name van 281 organisasies wat navorsing in die 
Sosiale Wetenskappe aan 104 universiteite en kolleges werklik onderneem of finansieer.

Ook die Britte kan as „research-minded" bestempel word, soos dit blyk nie alleen uit die navorsing wat deur instansies deur die regering in die lewe geroep en in stand gehou, gedoen word nie, maar o.a. ook uit die verhoogde toekennings aan die universiteite.

The Department of Scientific and Industrial Research is die organisasie van die Britse regering om navorsing op die gebied van die natuurwetenskappe en die nywerheid, met uitsluiting van die Medisyne en Landbou, te organiseer en aan te moedig. Die Departement hou 14 navorsingsorganisasies in stand.

The Social Survey is die regering se eenheid vir sosiale navorsing. Hierbenewens is daar 'n groot aantal onafhanklike navorsingsorganisasies. In die veld van die sosiale wetenskappe is die volgende o.a. bekend:

1. The National Institute of Economic and Social Research wat o.a. sy fondse van die Rockefeller- en Nuffieldstigtings verkry.

2. Political and Economic Planning Trust (bekend as PEP) vir ekonomiese en sosiale navorsing.

3. The Scottish Council for Research in Education.

4. The National Institute of Industrial Psychology en die

5. International African Institute.

Sosiale navorsing aan die Britse universiteite het snel uitgebrei as gevolg van toekennings uit openbare fondse deur die University Grants Committee. 'n Groot gedeelte van die geld is bestee aan die uitbreiding van doserende poste, maar die gevolg was die stigting van afdelings vir navorsing en die uitgee van tydskrifte om die resultate van hul navorsingswerk bekend te stel.

Ook in Nederland het navorsing en beplanning in die afgelope jare, veral na die vertroebeling van verhoudinge met Indonesië, snelle vooruitgang gemaak.

$\mathrm{Na}$ Wêreldoorlog II het die Centrale Organisatie voor ToegepastNatuurwetenschappelijk Onderzoek (T.N.O.) snel uitgebrei, sodat dit tans uit sowat 50 navorsingsinrigtings bestaan. T.N.O. kry sy fondse van die sentrale regering en die nywerheid.

In 1950 is die Nederlandse Organisatie voor Zuiver-Wetenschappelijk Onderzoek (Z.W.O.) deur wetgewing in die lewe geroep om navorsing op die gebied van die suiwer wetenskappe insluitende die geesteswetenschappen te bevorder. 
Op die Raad van Z.W.O. dien daar o.a. twee verteenwoordigers van elke universiteit, een vir die natuur- en biologiese wetenskappe en een vir die geesteswetenskappe.

Z.W.O. is vir ons van besondere belang omdat dit funksioneer soortgelyk aan ons eie Nasionale Raad vir Sosiale Navorsing. 'n Aanta] deskundige komitees adviseer die Raad i.v.m. die bevordering van navorsing en die toekenning van fondse aan indiwidue en inrigtings vir navorsing, publikasie en studiereise.

In verskeie lande van die wêreld bestaan die neiging tot koördinering van pogings en aansporing van navorsing op die gebied van die sosiale wetenskappe deur middel van navorsingsrade. In pamflette nrs. 3 en 6 in die reeks „Reports and Papers in the Social Sciences" getiteld „Research Councils in the Social Sciences" uitgegee deur UNESCO, word 'n oorsig gegee van sowat 20 navorsingsrade op die gebied van die sosiale wetenskappe in 14 verskillende lande, insluitende Suid-Afrika. Die funksies van die verskillende liggame varieer van koōrdinering, aanmoediging en bevordering van navorsing deur middel van toekennings tot die onderneem van navorsing.

Die Nasionale Raad vir Sosiale Navorsing in Suid-Afrika is in die lewe geroep omdat daar vir navorsing op die gebied van die sosiale wetenskappe in die kader van W.N.N.R. nie plek was nie. Die doel en funksie van die Raad is o.a. om met die navorsing op die gebied van die sosiale wetenskappe behulpsaam te wees, dit aan te moedig, te organiseer en te koördineer sonder om dit te probeer oorheers of te monopoliseer. Verdere funksies van die Nasionale Raad vir Sosiale Navorsing is o.m. om die beplanning van navorsingskemas aan te moedig en te onderneem; om te verseker dat gelde doeltreffend en ekonomies gebruik word; om waar nodig, liggame in die lewe te roep om langtermynnavorsingswerk te onderneem; om die opleiding van navorsers aan te moedig deur toekennings en beurse vir dié doel beskikbaar te stel; om te help met die publikasie van resultate van navorsingswerk; om biblioteekdienste te bevorder; om in die algemeen ' $n$ beleid t.o.v. navorsingswerk op te stel en om die behoeftes in verband met navorsingswerk aan die regering en die land voor te hou; om skenkings te verkry en te administreer; om 'n tydskrif, nl. Tydskrif vir Maatskaplike Navorsing, uit te gee deur middel waarvan die resultate van navorsingswerk bekend gestel kan word.

'n Aantal deskundige komitees, nl. vir Sosiologie, Opvoedkunde en Sielkunde, Ekonomie, Handel en Aardrykskunde, Afrikanistiek, Geskie- 
denis, Tale en Regte, adviseer die Raad t.o.v. beleid en toekennings op die onderskeie gebiede.

Die Nasionale Raad vir Sosiale Navorsing is 'n adviserende liggaam en onderneem self nie navorsingswerk nie, omdat die Raad oor geen eie personeel beskik nie. Die Nasionale Buro vir Opvoedkundige en Maatskaplike Navorsing verskaf sekretariële dienste aan die Raad, en die Direkteur van die Buro is ampshalwe lid van die Raad.

Wat sy organisasie en funksies betref, vertoon die Nasionale Raad vir Sosiale Navorsing ook 'n groot ooreenkoms met die Sweedse, Noorse en Britse Rade.

Die Nasionale Raad vir Sosiale Navorsing ontvang jaarliks $£ 40,000$ van die Sentrale Regering, wat in die vorm van toekennings beskikbaar gestel word om die koste verbonde aan navorsingsprojekte te bestry en om publikasies en navorsing oorsee moontlik te mak.

Dit is tans die beleid van die Raad om vir die sg. groot projekte 'n maksimum bedrag van $£ 9,000$ versprei oor 3 jaar toe te ken, d.w.s. $£ 3,000$ per jaar vir 3 jaar.

Die N.R.S.N. moes deur ervaring leer en wat sy beleid betref, is daar ' $n$ duidelike ontwikkelingsgang waar te neem. Dit is teenswoordig die beleid om toekennings aan universiteite, ander navorsingsliggame en indiwidue te makk, maar nie aan private instansies nie.

Belangrike vordering met navorsing op die gebied van die geesteswetenskappe is die afgelope aantal jare gemaak, maar ontwikkeling op die gebied van die natuurwetenskappe is na verhouding veel sneller. Die groot ontwikkeling op die gebied van die natuurwetenskappe stel die geesteswetenskappe voor 'n uitdaging. Dink maar aan die talle sosiale en sielkundige probleme wat deur outomatisasie alleen geskep kan word.

Lord Halsbury, besturende direkteur van Brittanje se National Research Development Corporation, spreek die mening uit in 'n artikel „Automation -- Verbal Fiction, Psychological Reality" dat outomatisasie as 'n materiële werklikheid 'n bron van groot rykdom is, en as 'n sielkundige werklikheid, 'n bron van angs.

Gulliver in "Automation and its Social Implications" toon aan tot welke mate outomatisasie in hoogs geindustraliseerde lande soos die V.S.A. en Rusland gevorder het. So word daar in een fabriek in die V.S.A. deur twee masjienoperateurs 1000 radiotoestelle per dag vervaardig, d.w.s. meer as wat 200 werkers met die ou metode kon regkry.

„In the U.S.S.R., a fully automatic plant makes aluminium pistons for heavy truck engines. No human hands intervene throughout the pro- 
cess and even waste metal is removed from machines automatically.

„In the United States automabile industry, the non-automated engine plant has almost died out for all practical purposes. At the Ford plant in Cleveland, for instance, one man runs a transfer machine performing more than 599 machine operations, whereas conventional methods required 35 to 70 men. Formerly, 400 workers took 40 minutes to turn out one engine block; now, under automated methods, 48 workers complete a block in less than half that time". (Gulliver).

Outomatisasie gaan groot probleme in die arbeids- en sosiale velde skep. Outomatisasie 'n bron van groot rykdom, maar ook 'n bron van angs!

Navorsing op die gebied van die geesteswetenskappe moet met navorsing op die gebied van die natuurwetenskappe tred hou om 'n ewewigstoestand te bewaar.

\section{P. M. ROBBERTSE.}

* Die skrywer hiervan is Direkteur van die Nasionale Buro vir Opvoedkundige en Maatskaplike Navorsing. - Red. 